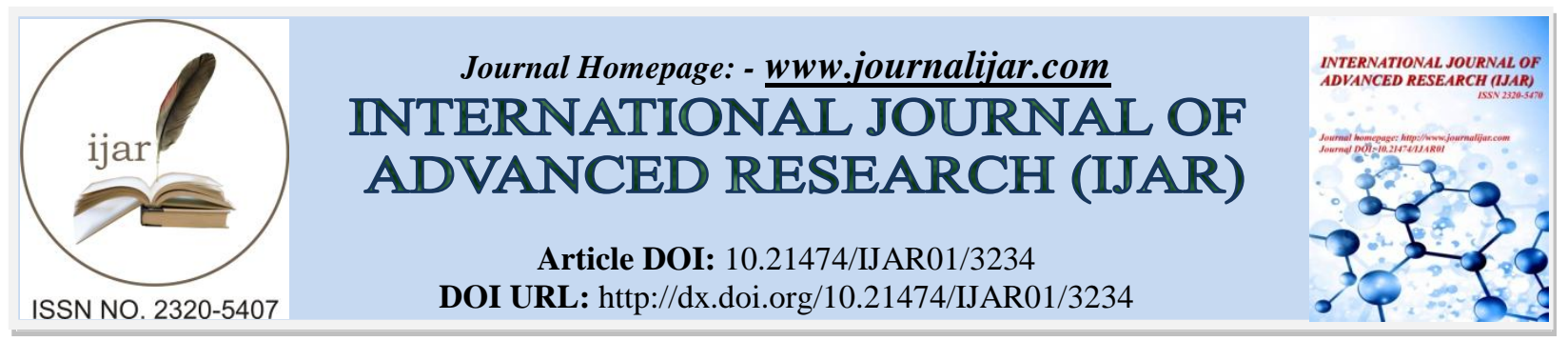

RESEARCH ARTICLE

\title{
THEORETICAL ASPECT OF SOCIAL COMPETENCE FORMATION IN TEACHING FOREIGN LANGUAGES
}

Omanov Pulat Habitovich

Uzbekistan State World Languages University, Scientific researcher

\section{Manuscript Info}

Manuscript History

Received: 09 December 2016

Final Accepted: 24 January 2017

Published: February 2017

Key words:-

Teaching, linguistics, culture, values, foreign languages, intercultural relations, communicative competence, socialcultural competence.

\section{Abstract}

The article is devoted to theoretical aspect of formation of socialcultural competence which is necessary in teaching foreign languages. After getting independence the educational system in Uzbekistan was changed by making a number of reforms aimed at preparing further generation with high intellectual development, moral and spiritual upbringing. Since obtaining national sovereignty the system of education is improving by embedment of new methods and models of teaching. The content of teaching, of course, contains teaching culture and spiritual heritage. Essential in this aspect becomes formation of the social-cultural competence in the process of teaching foreign languages.

Copy Right, IJAR, 2017,. All rights reserved.

\section{Methods and Materials:-}

The methodological ground of the present research includes theoretical issues of N. Muravyova, Z. Nikitenko, I. Bim, G. Ferapontov and others who devoted their investigation to the problems of integration of teaching culture into the process of teaching foreign languages. Methods used for the present research are: descriptive method - for description of the problem; method of observation - for revealing main aspects of forming of social-cultural competence and its integration into teaching process; componential analysis - for dividing the process of socialcultural competence formation into components; method of critical analysis of the researches done in the sphere of investigation.

\section{Results and Discussion:-}

The new model of education aims at effective teaching foreign languages and formation of educated personality. New approach in teaching foreign languages makes an accent at teachers training institutions. Teaching programmes should match new demands of theory and practice of teaching foreign languages.

Knowledge of a foreign language is based on not only language skills but on knowing cultural peculiarities and lingual behavior as well. As foreign languages serve as means of intercultural relations between countries, so they should maintain perfect dialogue of different cultures.

Integration of teaching culture in the process of foreign language teaching has become wide. Mastering a foreign language deals with mastering national culture of its native speakers, cultural background and ability to comprehend the mentality of its speakers in the process of communicative dialogue. 
The present manuscript explains the notion of social-cultural competence and its peculiarities of formation in the process of teaching foreign languages.

The aim of teaching a foreign language is formation of communicative competence, which includes lingual, socialcultural competence. The absence of social-cultural background knowledge will lead to incorrect communication and can't maintain communicative competence.

Social-cultural competence is an effective means of formation of a personality of a foreign language teacher. It brings to development of students' personal qualities such as creativity, new ideas, comprehension of communicant's psychological state, tolerance to diversity and another point of view, positive attitude to foreign culture and its bearers ${ }^{1}$.

Being the elements of culture, languages function in the frames of a definite culture. Students, who are taught these languages, should be aware of cultural peculiarities. National-cultural competence includes specifics of speech behavior of language native speakers and elements of social-cultural context: customs, traditions, norms, rules, social conditions, rituals, country study knowledge.

All these problems are attracting more attention of researchers who point the necessity of including teaching culture into the process of teaching foreign languages. N.G. Muravyova points: "Social-cultural competence is an integrative characteristics of a person, being aware of various social-cultural spheres and being able to communicate with different people basing on life experience" .

Learning the culture of the country of a foreign language develops mutual understanding, tolerance to each other, respect to another culture, comprehension of its peculiarities in the process of communication with foreigners ${ }^{3}$.

The most effective way of learning foreign language culture is living in that country, being involved into the atmosphere of culture, traditions, customs and social norms of the country of foreign language. But not all the learners have chance for it. So we should offer the most effective ways of development of social-cultural competence outside of authentic language sphere. ${ }^{4}$

\section{The development of social-cultural competence includes 4 main steps:-}

1. Social-cultural knowledge - materials about the country of a foreign language, its spiritual values and cultural traditions, peculiarities of national mentality;

2. Experience of communication with foreigners - choice of the style of communication, correct expression of thoughts, and correct explanation of phenomena of foreign culture;

3. Personal attitude to the facts of foreign culture - tolerance and ability to avoid social-cultural conflicts in communication with foreigners;

4. Correct usage of socially marked language units in various spheres of cultural communication, comprehension of diversity and difference of foreign culture with native one.

We see that a language is a means of transformation of cultural experience of a country and reflection of historical changes.

Social-cultural competence suggests that knowing the norms of speech behavior gives opportunity to reveal nationally marked lexics in the texts of different styles.

Formation of social-cultural competence deals with practical, developing and upbringing functions of a language. The upbringing function is the most essential as it helps to increase the feeling of patriotism and feeling of internationalism in a young learner. Learning English, we form comprehension of world culture in a person's mentality. We compare lingual phenomena, customs, traditions, art, and way of life of people.

${ }^{1}$ Ferapontov G.A. Laboratory of social-cultural and cross-cultural education. - Novosibirsk, 2001. - 273 p.

${ }^{2}$ Muravyova N.G. The notion of social-cultural competence in modern science and educational practice //The Journal of Tyumen State University. - 2011. - № 9. - PP. 141-148.

${ }^{3}$ Nikitenko Z.N. Specifics of teaching english in primary school. - Moscow: Pedagogical university, 2010. - PP. 115 .

${ }^{4}$ Bim I.L. The content of teching English in basic course. // Foreign languages at school.- 1996. - № 2. - PP.11. 
A.B. Minenko identifies social-cultural content of communicative competence with a) country study, б) language study, в) culture study, г) culturology 5 .

Social-cultural component in teaching a foreign language creates the basis of background knowledge about realias, tastes, customs, and traditions of the country of the learned language. All these elements are necessary in the speech act, verbal and non-verbal behavior and are included into the content of national culture. This component has a vast potential in the dialogue of cultures and introduction with national cultures in the development of humanity culture.

\section{Conclusion:-}

The analysis of different explanations of the notion "social-cultural competence" lets conclude that this competence is built on ability to reveal similar and different points between various countries and civilizations, ability to represent native country and its culture.

In this way, the context of professional training of teachers includes ability to interconnect with representatives of foreign culture, ability to interconnect with pupils as they are also representatives of different cultures though they speak the same language.

The result of social-cultural education is formation of social-cultural competence which leads to successful intercultural communication. Introduction with the culture of foreign language country takes place by comparing and evaluating of earlier obtained knowledge and new knowledge in this aspect. Comparison reveals specifics and similarities between different cultures and brings to kind relations and respect to different countries, people and their traditions.

\footnotetext{
${ }^{5}$ http://nsportal.ru/shkola/inostrannye-yazyki/library/2013/05/13/sotsiokulturnaya-kompetentsiya-v-prepodavanii
} 